\title{
ijurr
}

\section{Urban Political Ecology Beyond Methodological Cityism}

\begin{tabular}{|r|l|}
\hline Journal: & International Journal of Urban and Regional Research \\
\hline Manuscript ID & IJURR-Art-3491.R3 \\
\hline Manuscript Type: & Article \\
\hline $\begin{array}{r}\text { Please choose one or two } \\
\text { subject categories that best } \\
\text { describe the article's concerns: }\end{array}$ & $\begin{array}{l}7 \text { Theoretical debates \& reviews (state, neoliberalism, consumption sector, } \\
\text { \& non-economic migration) }\end{array}$ \\
\hline $\begin{array}{r}\text { Which world region(s) does the } \\
\text { article focus on? Select up to } \\
\text { five.: }\end{array}$ & $\begin{array}{l}\text { planetary urbanization, urban political ecology, the site multiple, } \\
\text { methodological cityism, urban metabolism }\end{array}$ \\
\hline $\begin{array}{r}\text { Which country/countries does } \\
\text { the paper focus on? Select up } \\
\text { to five.: }\end{array}$ & \\
\hline $\begin{array}{r}\text { Which city/cities does the } \\
\text { article focus on? List up to five } \\
\text { cities.: }\end{array}$ & x \\
\hline
\end{tabular}




\title{
Urban Political Ecology Beyond Methodological Cityism
}

\author{
Creighton Connolly, \\ Asia Research Institute, \\ National University of Singapore, \\ AS8 \#07-49, \\ 10 Kent Ridge Crescent, \\ 119260, Singapore \\ Email: ariccp@nus.edu.sg
}

\begin{abstract}
The concept of planetary urbanization has emerged in recent years amongst neoLefebvrian urban scholars who see urbanization as a process taking place at all spatial scales. This paper analyzes recent critiques of the urban political ecology (UPE) literature which argue that much of the work in the field has been guilty of focusing exclusively on the traditional bounded city unit, rather than urbanization as a process. In response, the paper reviews various strands of the UPE literature which have (always) moved beyond 'the city' to consider the various metabolisms and circulations of humans and non-humans connecting cities with places outside of their borders at a variety of scales. Furthermore, it suggests how these approaches can productively work with the insights of the planetary urbanization literature, in considering both the changing nature of urbanization, and also the socio-ecological and political implications of these changes. Finally, the paper suggests how the methodological approach of the 'site multiple' and its focus on everyday practices and lived experiences can be useful for researching diverse urban phenomena and their more-than-urban connections.
\end{abstract}

Keywords: urban political ecology, methodological cityism, planetary urbanization, urban metabolism, the site multiple

Acknowledgements: This paper was initially developed for a panel at the RGS-IBG Annual Meeting in 2015, titled 'Cityness and the Site Multiple: Urban Political Ecology Beyond Methodological Cityism'. Thanks are due to Ingrid Behrsin for her invitation to co-organize the panel, and her subsequent comments on my paper, as well as those of the other participants. A more recent version of the paper received valuable comments from the members of the Politics, Economies and Space (PEAS) Reading Group at the National University of Singapore in early 2017. Thanks are also due to Matthew Gandy and three anonymous referees for helping to further refine and clarify my writing 


\section{Introduction}

In a recent article 'Urbanizing Urban Political Ecology: A Critique of Methodological Cityism', authors Hillary Angelo and David Wachsmuth tell the story of urban political ecology (hereafter, UPE) in the context of planetary urbanization (Angelo and Wachsmuth, 2015). The concept of planetary urbanization has emerged in recent years amongst neo-Lefebvrian urban scholars who see urbanization as a process taking place at all spatial scales. Gone are the days when cities were surrounded by walls to clearly demarcate the urban from the rural (see Keil and Graham, 1998). With processes such as 'ruralization' (Mitchell, 2008), and 'postsuburbanization' (Keil and MacDonald, 2016), we are now confronted with the difficult task of making sense of the vast networks that are constitutive of cities and urbanization. Scholars such as Neil Brenner and David Wachsmuth have thus been highly critical of 'methodologically territorialist' approaches, which, in their view, treat the urban as a distinct, bounded settlement type that is separate from non-urban zones located elsewhere (see Brenner, 2014; Brenner and Schmid, 2014; Wachsmuth, 2014). These interventions have been highly provocative, and have already inspired others to take up their call in different forms (Arboleda, 2016b; Rice and Tyner, 2017; Saguin, 2017). ${ }^{1}$

This paper intends to spark some reflection on the claims made by Brenner, Angelo and Wachsmuth and others. While sympathetic to their call for more engagement with urbanization as a process by focusing on empirical sites outside of conventional city limits, I find that their critique misses out on a productive opportunity to engage with some rich strands of research within the UPE literature. I further contend that the hitherto lack of critical response to their provocation risks foregoing a potentially lively debate between scholars of planetary urbanization and urban political ecology. The paper thus reviews the arguments put forth by Angelo and Wachsmuth, while also critically examining claims made by other urban political ecologists who have adopted the critiques of planetary urbanization and methodological cityism in recent work.

However, rather than adopting the analytical approach of critique utilized by Angelo and Wachsmuth and other critical scholars, this paper seeks to respond by way of composition. As Bruno Latour (2004) has argued, such forms of critique have 'run out of steam'. Rather than run-

\footnotetext{
${ }^{1}$ Wachsmuth (2014) and Angelo (2016) have also developed similar critiques elsewhere, which echo their joint critique (Angelo and Wachsmuth, 2015).
} 
ning the risk of constructing another straw-man critique, or arguing that one theory is somehow better or 'more realistic' than another, I adopt a mode of composition which remains open to the insights of planetary urbanization scholars (see Latour, 2010; Lepawsky et al., 2015). But in order to begin the composition, it is first necessary to 'decompose' the arguments against urban political ecology, before being able to 'recompose' and reassemble a political ecological approach to studying urbanization as process (see Latour, 2010). In the next section, I thus deconstruct the criticisms of UPE, and show how its flagship concept of urban metabolism actually enabled urban political ecologists to problematize and question the binaries (between, e.g. urban/rural; society/nature) that had for so long plagued urban studies and previous forms of ecological thinking. Furthermore, I show how this lens has enabled the sub-field to highlight (and explore alternatives to) the deeply uneven power relations at work through the urbanisation of nature as spatial process (see Heynen 2014).

Subsequently, I suggest the usefulness of the methodological approach of the 'site multiple' advocated by Lepawsky and colleagues (2015), in addition to related methodological sensibilities and tools that can be used for researching diverse urban phenomena and their multi-scalar connections. The site multiple is influenced by poststructural thinking, which advocates a focus on the everyday practices and experiences that are constitutive of cities and their more-thanurban geographies. This insight is based on the recognition that sites are enacted through practices, which are not spatially bound, or how, paraphrasing Tsing (2005: 1): urban connections are everywhere. This means that, as Latour (2005: 27) put it, our research must start, 'in the middle of things'. While not developed from a UPE lens, these are suggested as a form of 'methodologically adventurous' approaches that Angelo and Wachsmuth (2015: 25) have argued are necessary to understand the metabolic processes and socio-environmental implications bound up with extended forms of urbanisation. As I demonstrate, such approaches are helpful for defining the actors, sites and processes which are constitutive of contemporary urbanization, rather than assuming a priori how the urban is composed.

Finally, in the fourth section, I point to several empirical and conceptual strands of work within the UPE literature which has sought to highlight the changing nature of cities and their more-than-urban geographies. The cases chosen illustrate the creative ways in which urban political ecologists are furthering UPE's conceptual legacy to show not only how cities are produced through socio-natural metabolic flows originating 'elsewhere'; but also that cities and their spe- 
cific sociopolitical contexts and spatial configurations have strong implications for how these various non-human natures are urbanized. These bodies of work are by no means the only ways that urban political ecologists have extended their lens beyond the city as a unit of analysis, but are rather indicative of emergent approaches and engagements. The goal for this paper is thus to suggest different ways of researching urbanization that can work together in determining what constitutes the urban and what sites are enrolled in the process of urbanization. The paper concludes that one way of doing so is to take a methodological focus on the everyday practices and experiences of actors that are constitutive of cities and their more-than-urban geographies (see also, Lawhon et al., 2014; McFarlane and Silver, 2017).

\section{Methodological cityism in UPE?}

In their paper, Angelo and Wachsmuth (2015) excavate the initial premises and goals of the UPE literature, and how they perceive it to have derailed from this early trajectory. Subsequently, they develop a Lefebvrian-inspired critique of UPE and its alleged 'methodological cityism' and propose some ways in which the sub-discipline could: 'reorient itself to being a political ecology of urbanization rather than a political ecology of cities' (Angelo and Wachsumth, 2015: 17). ${ }^{2}$ Following a brief review of the early UPE literature, Angelo and Wachsmuth surmise that the sub-field has taken up two primary goals since its inception. First, to theorize urbanization as a process that involves the transformation of society and nature into two inseparable wholes, and; second, to bring political ecological approaches into the mainstream of critical urban studies. One of Angelo and Wachsmuth's chief disappointments with the UPE literature is the abandonment of its 'Lefebvrian roots', which has, in their opinion, resulted in the sub-field's inability to fully theorize urbanization as process. As they write: 'there was another goal in early UPE programmatic statements that has largely fallen by the wayside: to mobilise a Lefebvrian theoretical framework to trouble traditional distinctions between urban/rural and society/nature by exploring urbanization as a global process' (Angelo and Wachsmuth, 2015: 16).

However, it is surprising that Angelo and Wachsmuth ignore the crucial issue of class struggle in shaping processes of urbanization. Lefebvre's understanding of urbanisation - and the

\footnotetext{
${ }^{2}$ Angelo and Wachsmuth, as well as other proponents of planetary urbanization thinking draw Largely on Lefebvre's The Urban Revolution (2003), where Lefebvre discusses the explosion of urban society beyond the traditional confines of the city.
} 
significance of his legacy - was not only about the 'explosion' of urban societies, but also that it is a highly uneven and socially unjust process which reinforces class divides and power relations (Derickson, 2015; Lefebvre, 2003; Harvey 2008; Scott and Storper, 2015). ${ }^{3}$ Much of Lefebvrian UPE and related urban research does do precisely this, as Arboleda (2016b) has recently shown in his analysis of the commodity boom and extractive industries in Latin America (see also Newman, 2015). Moreover, as Alex Loftus (2012) has pointed out, much of Lefebvre's writing actually saw the urban as the antithesis of nature which has led many UPE scholars to draw upon Marxian political economy which understands nature as integral to the processes feeding urbanization (see Keil, 2003; Heynen, 2014). Furthermore, UPE does not have any fixed theoretical or methodological tenets, which means that the sub-discipline has always been a rapprochement between ecological thinking, political economy, urban studies, and critical social and cultural theory (see Swyngedouw, 1996; Braun, 2005; Heynen, 2014). This is a vital characteristic of the UPE literature, which gives it much of its vibrancy and analytical strength.

For instance, Erik Swyngedouw's (1996) paper 'The city as hybrid: on nature, society, and cyborg urbanization' utilizes an eco-Marxian approach to political ecology and more specifically, the 'production of nature' thesis (Smith, 1984), to posit that the city and urbanization in general are products of metabolic processes of what he termed 'socionatural' transformations. In particular, the paper introduced the concept of socio-natural metabolism, which has provided much of the analytical strength of the UPE literature and has substantially transformed thinking on the nature of urbanization and cities. The notion of metabolism is key to UPE's definition of the city, which is conceptualized as 'a sub-system located within a larger socio-spatial system', for example an urban region, which are linked through various socio-natural metabolisms (Keil and Macdonald, 2016: 1518). This is an inherently relational understanding of the city, which contrasts to the fixed view of the city that is imagined in the critiques of methodological cityism. As Lockhart (2015) reminds us, this understanding of cities originates in Marx and Engels' initial conceptualisation of the dialectic between town and country and by extension, the naturesociety dialectic. Yet, Swyngedouw's work has been equally influenced by poststructural metaphors and heuristic devices such as Haraway’s ‘cyborgs' (Haraway, 1991) and Latour's 'quasi-

\footnotetext{
${ }^{3}$ This is also powerfully demonstrated in Mike Davis' work on Los Angeles (Davis, 1998) and Las Vegas (Davis, 2002) which has been highly influential in urban political ecology. Thanks to an anonymous reviewer for highlighting this point.
} 
objects' (Latour, 1993) - terms that are now very commonplace in the literature on urban political ecology, and in the social-sciences more broadly.

More to the crux of their argument, Angelo and Wachsmuth assert that UPE has not developed a specific research program for tracing forms and processes of urbanization beyond the realm of the city. As they put it: 'the bulk of empirical research in urban political ecology has been tethered exclusively to the city, in both its site selection and analytical framework' (Angelo and Wachsmuth, 2015: 5). They find this to be a surprising contradiction, given that the limited attention to the expansive socio-natural character of urbanization in both political ecology and urban research was one of the initial motivations for UPE in the first place. Angelo and Wachsmuth suggest that one potential reason for this shortcoming may be that while UPE scholars widely recognize the global production of uneven urban environments, they have primarily focused on singular, bounded (urban) case studies in supporting this observation. To support this claim, they point out that the edited volume, In the Nature of Cities (Heynen et al., 2006) only includes one case study which focuses on the political ecology of urbanization as process, extending beyond the realm of individual cities. They additionally cite Erik Swyngedouw's previously mentioned paper 'The city as hybrid' as an example, due to his interchangeable use of the terms 'the city' and 'urbanization' (Swyngedouw, 1996). ${ }^{4}$

Yet, the work of Swyngedouw and other urban political ecologists actually tends to focus on elements of nature which permeate cities - both by design and unintentionally. In this way, such UPE research - while perhaps focused on a particular urban site - demonstrates that the socio-natural flows and interactions taking place within the city are not only bounded within that local site. For example, Swyngedouw's classic (1996: 66-67) observation that if he were to take some of the water flowing in the city, and capture it in a cup, he would: "pass with continuity from the local to the global, from the human to the nonhuman'. To demonstrate this, he uses the case of Los Angeles, which indicates how the socio-ecological transformation of desert landscapes and the subsequent manufacture of 'silicon' landscapes is paralleled by the simultaneous

\footnotetext{
${ }^{4}$ This is one illustration of the way that Swyngedouw's work has been caricatured by Angelo and Wachsmuth in their critique of previous writing in UPE. While Swyngedouw does use the terms 'the city' and 'the urban' interchangeably, this is not to say that there is no difference between the two. Indeed, it is clear that his analysis is intended to apply to both the political ecology of the city and urbanization.
} 
remaking of the surrounding watersheds and development of new engineering projects (see also, Davis, 1998; 2002; Ross, 2011; Gandy, 2014).

As such, Loftus and March (2016: 59) point out that urban political ecology has actually 'never been constrained by the urban form but has, rather, developed an approach that always moves beyond the local to understand the broader ensemble of socio-ecological relations out of which specific urban forms are produced'. Similarly, Darling (2005) has pointed to UPE as a notable exception in urban studies which challenges traditional divisions between the urban and rural. This simultaneous transformation of the urban and rural through urbanization is also powerfully illustrated in Swyngedouw's most recent monograph, Liquid Power, which traces the history of water engineering projects in Spain since the turn of the 20th century (Swyngedouw, 2015). Using a UPE lens, the book convincingly demonstrates how local, regional and national socio-natures are combined with engineering narratives, land speculation and global water and money flows. In this example, the urbanization of water is deeply implicated in the political ecology of the local and national state, as well as regional and global hydrological cycles.

Similarly, Maria Kaika’s (2005) book, City of Flows, seamlessly teases out the material and infrastructural connections forming the 'socio-spatial continuum' between city and countryside in (and outside of) Athens and London. Nonetheless, Angelo and Wachsmuth critique Kaika's book as a prime example of the 'methodological cityism' which they find to be 'rampant' in UPE (Angelo and Wachsmuth, 2015: 20). Though Kaika certainly does ask how cities like London and Athens are premised upon the metabolization of nature, she also looks at spaces well outside these cities to convey how 'nature' and 'the city' are hybrid entities that mutually transform one another. Moreover, the point of Kaika's work, is not to merely show how Athens (or London, or New York) are socionatural, as Angelo and Wachsmuth (2015) assert, but rather to demonstrate the choreography of materials, actors and places that are enrolled through the process of urbanization.

The dialectical relationship between city and countryside is thus central to urban political ecologists' conceptualization of cities. One of the foundational texts in this regard is Bill Cronon's (1991) book, Nature's Metropolis, which argues that urban and rural landscapes...are not two places but one. They created each other, they transformed each other's environments and economies, and they now depend on each other for survival" (Cronon, 1991: 384). In this way, Swyngedouw (1997: 329) writes that 'the city is a giant social process of perpetual transfor- 
mation of nature'. While Cronon's work is not urban political ecology per se, it has had considerable influence over the subsequent body of work to emerge within the UPE literature, as Angelo and Wachsmuth rightly point out.

Yet, while Angelo and Wachsmuth (and others) argue for a reconceptualisation of the urban in UPE as a global or 'planetary' process, it is clear that they do not refer to literally the whole world. Rather, there are particular sites that become useful for the process of urbanization due to particular (political, geographic or environmental) characteristics. What makes these sites in particular important for understanding urbanization then, would be worth explicating, and perhaps differentiating from their urban (city) counterparts. In other words, what characterizes these peripheral regions, both in a phenomenological and an ontological sense?

Furthermore, I would argue that urbanization per se is (and should not be) the sole focus of UPE. As convincingly demonstrated by Heynen, Kaika and Swyngedouw (2006) in their flagship book, In the Nature of Cities, the objects of analysis range from mundane topics such as food (Heynen, 2006) to lawns (Robbins, 2007), gardens (Parés et al., 2013) and these objects' metabolic and circular flows which are shown to produce different effects. In addition, the roles of various non-human actors that appear in the book's case studies illustrate UPE's success in presenting cities as dynamic socio-ecological sites (see Braun, 2005; Gandy, 2014). Indeed, as Scott and Storper (2015: 4) have rightly argued: 'any attempt to build a general concept of the city is further vitiated by the fact that cities also typically contain an enormous diversity of empirical phenomena'. This theoretical and empirical vibrancy within UPE accounts for the vibrancy and richness of the field, which would be a shame to lose sight of. Unfortunately, as with many critiques, Angelo and Wachsmuth and others focus on the perceived shortcomings of the UPE literature, while downplaying many of these considerable assets.

In search of 'the city'

Despite his criticisms of the UPE literature, Wachsmuth's recent (2014) exegesis of the the city as a 'concept of practice' proposes an interesting third way for bridging the perceived impasse highlighted by planetary urbanisation scholars. On one hand, he recognizes the futility of the city concept for characterising emergent patterns of urbanization, whilst on the other hand emphasising the ongoing utility of the city concept to urban theory and everyday experience (Wachsmuth, 2014). For instance, Wachsmuth suggests treating the city as a 'concept of prac- 
tice', or as a representation of people's quotidian experience of and relationship to cities and processes of urbanization (see also, Loftus, 2012). Similarly, Lawhon and colleagues (2014: 507) have advocated the approach of 'situated UPE', which seeks to (re)theorize cities 'from the bottom up', through the everyday practices of urban actors. These insights accord with Bunnell and Maringanti's critique of 'metrocentricity' (2010), in acknowledging that, while critical urban theorists have recognized emergent differences in the process of urbanization, these patterns have not necessarily impacted the way that people think of cities in their everyday consciousness, nor their personal experience of the urban environment. ${ }^{5}$

These studies suggest that maintaining a focus on the city as an identifiable and specific space of social and economic relations is important in comprehending the changing nature of urbanization as understood by city dwellers themselves. Such forms of analysis could also be extrapolated to non-cities such as Huasco (see Arboleda, 2016b), or exurban fringes (Walker and Fortmann, 2003; Cadieux, 2008, Taylor and Hurley, 2016) to identify how these spaces are being impacted by urbanization, as understood by local inhabitants. Importantly, as Lawhon et al. (2014) attest, 'everyday urbanisms' are thus also important to understand how urbanisation processes in the global South may be different to those in the global North, where much urban theory originates (see also, Derickson, 2015; McFarlane and Silver, 2017). This is also an aspect of the planetary urbanization literature that has recently attracted critique from various urban theorists who have argued that its focus on universalism omits the importance of different forms and routes of knowledge production (Derickson, 2015; McLean, 2017).

In this way, urban scholars have started to describe cities as places (or things) 'in the making' (Simone 2010: 3), rather than determinate, bounded units. For instance, Lepawsky and colleagues (2015: 187) have developed a methodological sensibility which they call 'the site multiple' to investigate the more-than-urban geographies that works with (rather than against) the critiques of the planetary urbanization literature. The concept of the site multiple originates from Annemarie Mol's (2002) concept of the body multiple. Much like Mol's use of the term, the site multiple refers to a site (e.g. 'the city') that is enacted through practices. In my view, this concept has considerable implications for where we conduct our research as urban scholars. Ra-

\footnotetext{
5 Metrocentricity is Bunnell and Maringanti's (2010) term to describe the tendency to focus on global cities in urban and regional research, and the conceptualisation of cities existing a priori to actually conducting the research.
} 
ther than being a single, discernible entity, the site multiple helps us to understand how the urban is actually distributed, patchy, and not necessarily one coherent space. The site multiple thus posits that we as researchers should only determine in advance the empirical phenomena that we are interested in studying, while letting the various actors, objects and practices that constitute that phenomena to dictate where our research might lead us. This may ultimately lead us to sites that may not be considered 'urban' in a traditional sense, but equally cannot be fully determined in advance of doing the research.

The concept of the site multiple echoes Lepawsky and Mather's (2011) call for research which focuses on 'actions' (rather than just 'things') as a way of exploring the 'boundaries and edges' of the empirical phenomena being studied - in this case, the city. As they argue, 'when searching for boundaries and edges we can follow actions, but in advance of analysis we need to remain "as undecided as possible on which elements will be tied together"" (Lepawsky and Mather, 2011: 243, citing Latour, 1987: 175). The methodological and conceptual focus on boundaries and edges is thus helpful in understanding how the travels of various materials composing the urban constitute processes of circulation and metabolism, and their urban political ecologies. As Lepawsky and colleagues (2015: 187) put it, the methodological sensibilities of the site multiple and boundaries and edges allow us to: 'keep open the very question of what composes cityness'. Cityness refers to Simone's (2010) term, which recognizes that cities may be made up of something other or more than the urban. For example, Whatmore (1999: 33) has argued for tracing the 'routine interweavings' operating in and through cities, which link the various people, nonhumans, resources and infrastructures comprising urban spaces with other "nonurban' sites. This includes our own presence and interaction in the field, which Bunnell and Maringanti (2010: 419) have argued is central for moving beyond metrocentricity in urban studies.

As Lepawsky and colleagues (2015) point out, while the site multiple is different from multi-sited, the two are certainly interrelated. On one hand, multi-sited implies a methodological approach to tracing one phenomena through different related sites, while the site multiple, recognizes that phenomena (and the places in which they exist) are enacted through practices, which are diffuse and scattered (often unevenly) across space. In tracing the particular spatial forms brought about by planetary or extended urbanization, it is thus important to understand the different actors and sites that are involved in shaping them. Moreover, as political ecologists such 
as Freidberg $(2001 ; 2004)$ have demonstrated, it is important to conduct analysis in several geographical sites in order to link place-specific conflicts and struggles to regional, national and global political-economic processes (see also Robbins, 2007). This will also help to further break down the divide that has been identified between studies in the global North and South by postcolonial scholars such as Ananya Roy, which is something that UPE has been making great strides in (e.g. Ranganathan and Balazs, 2015; McFarlane et al., 2016; Cornea et al., 2017).

Furthermore, as noted above, we also need to move beyond studies of urban infrastructure and spatial forms to understand the everyday experiences of cities (and conversely, 'noncities'), and how these vary from place to place (Lawhon et al, 2014). The site multiple can thus be useful in determining where to start in empirical studies of urbanization, in that it allows research participants to identify which areas are most significant for investigating the questions we are asking, and by introducing us to other relevant stakeholders within their networks (see also, Cook, 2006; Crang \& Cook, 2007). It also helps to trace the contingent relations at various scales that are constitutive of urban sites and their myriad global connections, and avoid a 'onesize-fitsall' narrative of how the urban is composed and how to study it (Tsing, 2005). In other words, viewing sites as multiple might enable us to go beyond global/local, urban/rural dichotomies to chart an alternative way of understanding the empirical and conceptual connections between various sites (see Robinson, 2016).

Urban political ecology and the nature of urbanization

In their paper, Angelo and Wachsmuth (2015) point to several bodies of critical urban studies which they argue have done a better job of investigating urbanization processes that exceed the confines of the traditional city. Among these are 'worlding cities' (Roy and Ong, 2011) and 'assemblage urbanism' (Farias and Bender, 2010; Brenner et al., 2011; McFarlane, 2011), which seek to 'chart urban processes that incorporate nature and extend beyond the boundaries of the traditional city' (Angelo and Wachsmuth, 2015: 24). However, apart from a few brief examples in the conclusion, they overlook the components of the urban political ecology literature which have actually gone beyond the city to consider their transnational connections and integra- 
tion within their broader regions and hinterlands. ${ }^{6}$ In this penultimate section, I thus provide an overview of several of these strands which have (explicitly or not) sought to grapple with the expansive nature of contemporary urbanization and its socio-ecological effects. They are included here to demonstrate that, rather than solely focusing on 'nature in the city', UPE is actually a much broader form of analysis which can highlight the various metabolisms and circulations of humans and non-humans connecting cities with places outside their borders at a variety of scales (Swyngedouw, 2006; Loftus, 2006; Keil and Macdonald, 2016). I also indicate how these approaches have made use of the methodological focus on practices put forth in the previous section, and where these can be further developed.

As indicated above, the concept of urban metabolism has been a central conceptual device in urban political ecology, which has been continually expanded by urban political ecologists to analyze emergent socio-spatial formations and their political-ecological effects (Keil and Boudreau, 2006; Swyngedouw, 2006). Much of this work has also continued to problematize boundaries and divides between the urban and rural, while explicating the implications for local actors - especially those marginalized or otherwise negatively affected - through such transformations (Gandy, 2004; Loftus, 2006). Attention to rural-urban and socio-natural metabolisms are thus of critical importance to understanding the spatial dynamics, as well as the socio-ecological implications of planetary urbanization.

In this regard, Gustafson and colleagues (2014: 665) have developed the approach of 'megapolitan political ecology' to work 'across the nature-society and urban-rural matrix to account for the flows of people, objects, resources, and knowledge that constitute regional urbanization'. The authors use the term 'megapolitan region' to capture the connections between multiple cities (of various sizes) and their hinterlands which allows us to move beyond static definitions of the city. Gustafson and colleagues additionally argue for the need to transform research questions to consider the connections between what they call 'regional urbanization' and the processes of environmental change bound up with it. They use this regional lens to build on Cronon's earlier (1991) insights into the urban-hinterland relationships and the related metabolic functions of the city which, as noted above, are foundational to the UPE literature. For instance,

\footnotetext{
${ }^{6}$ Moreover, the examples chosen do not actually track urbanisation out of the city, but can rather be seen as cases of 'nature in the city', which Angelo and Wachsmuth are so critical of.
} 
drawing on the work of Karl Marx (1976) and Neil Smith (2006), Gustafson and colleagues (2014: 667) argue that the importance of the concept of metabolism is that it illustrates how 'new socio-spatial formations, collaborative enmeshing of nature and society and uneven social relations come into being'. As such, the approach engages with key insights of the planetary urbanization literature, while also maintaining a dialectical urban political ecology framework.

As Gustafson and colleagues note, megapolitan political ecology echoes work in the exurban political ecology literature, which considers the transformation of historically rural places through processes of ex-urbanization and urban-rural or 'amenity' migration (see Walker and Fortmann, 2003; Cadieux, 2008; Hiner, 2014; Hurley et al. 2017). While not explicitly utilising the concept of metabolism, the exurban political ecology literature does enable an understanding of rural-urban metabolisms through an examination of the practices and underlying conditions that affect the nature of urban metabolisms and their effects. In this way, the exurban political ecology literature makes use of the methodological focus on practices advocated through writing on everyday urbanisms (discussed in the next section) by highlighting enduring rural practices in urbanizing areas and the import of urban practices into historically rural places. The literature additionally utilizes the concept of landscape to interrogate urban, suburban and rural morphologies while avoiding the rural-urban dichotomy (see Hiner, 2016).

Similarly, Keil and Macdonald (2016) have recently put the UPE literature in conversation with the literature on suburbanization and post-suburbanization in grappling with the regulation of urban expansion, agglomeration, and 'metropolisation' (Parés et al., 2013; Meijers et al., 2014). They argue that the UPE lens is useful for examining the 'metabolic and discursive constellations' engendered by suburbanization across different spatial scales, and how this in turn enables conceptualisation of the city as a sub-system located within a broader urban region. In particular, they use the case of urban greenbelts to illustrate how nature, in the form of the urban environment, has become a key component of urban policy tools which are used to control the form and extent of urban-regional development. Yet, as a form of 'produced nature', Keil and Macdonald argue that greenbelts actually serve to obscure the divide between rural and urban, even as they are an attempt to demarcate a 'natural' boundary of the city. Much like the aforementioned approaches of ‘megapolitan' and ‘exurban’ political ecology, Keil and Macdonald (2016) demonstrate how work in urban political ecology is much more than a study of "nature in 
the city' through their examination of the various forms of negotiation and socio-ecological metabolisms that take place on the urban fringe.

Engagements with landscape political ecology (LPE) additionally provide a productive lens for conceptualizing extensive forms of urbanization through the focus on landscape as a hybrid urban/rural or cultural/natural entity (see Walker and Fortmann, 2003; Neumann, 2011; Connolly, 2017). In such a way, political ecologists have drawn attention to the ideologies and discursive strategies bound up with the transformation of urban space, seen, for example, in Paul Robbins' and others' work on the suburban 'lawnscape' (see Robbins, 2007; Robbins and Sharp, 2003). This is an approach that I developed previously to analyse the recent transformation of urban environments through the highly controversial phenomenon of 'swiftlet farming' in Malaysia, which involves the utilisation of existing commercial or residential buildings in cities to harvest the edible nests of swiftlets (see Connolly, 2016; 2017). This practice encourages swiftlets to nest in urban structures rather than caves (their 'natural' habitat), which has had significant impacts on public health, well-being and urban heritage, as well as ecological implications. Such cases speak further to the agency attributed to the non-human in UPE analyses, which illustrate the crucial role of animals in altering urban form, aesthetics and everyday life, in often unanticipated ways (see, e.g. Braun, 2005; Yeo and Neo, 2010; Instone and Sweeney, 2014).

In a similar vein, recent work in UPE on the expansion of urban agriculture (UA) seems to be a productive way of considering how UA projects 'are reshaping urban landscapes, and experimenting with alternatives to the capitalist organisation of urban life' (Tornaghi, 2014: 551). Like the exurban political ecology literature and the swiftlet farming case mentioned above, UPE work on urban agriculture further reinforces how the import of traditionally rural (or agricultural) practices fundamentally changes the nature and everyday experience of urban (and agricultural) landscapes (see, e.g. Freidberg, 2001). As Tornaghi (2014) has pointed out, for example, the case of UA poses difficult questions related to how urban planners and policy makers will make space for agriculture in the city. Yet, given the emphasis on action-research in UPE, she notes that the sub-field can be at the forefront of efforts to address this question, in collaboration with grassroots groups and urban policy makers. Moreover, Colasanti and colleagues (2012) make the case that UPE can also provide a more critical lens for revealing the potentially detrimental effects of the socio-ecological metabolisms and injustices created through UA projects, which are typically framed under the guise of sustainable city development and food security initiatives. 
Such cases thereby demonstrate how new modes of production and socio-ecological interventions can bring about 'a dramatic rewriting of urban landscapes and urban-nature relationships', which urban political ecologists are particularly well-placed to explore (Keil and Graham, 1998: 106). Work on 'eco' and 'smart' cities is another example of the ways in which urban political ecologists are beginning to explore the political, social and ecological ramifications bound up with the transformation of contemporary (and future) cities (e.g. Pow and Neo, 2013; Neo and Pow, 2015). As Neo and Pow (2015: 402) note, eco-city development 'positively cries out for urban political-ecology analysis' given its embeddedness in circulations of global capital, infrastructural networks, resource distribution, and the power of discourse in legitimising their development. More importantly, such studies reveal the profound socio-ecological injustices bound up with seemingly benevolent attempts at restructuring urban society.

Finally, infrastructure has continued to be a considerable topic of interest for urban political ecologists since the pioneering studies in the field, and much of this interest has focused on water infrastructure, in particular. ${ }^{7}$ In addition to the studies by Kaika (2005) and Swyngedouw (2004) discussed above, there is now a new wave of engagement with urban (water) infrastructure that has provided an additional way of understanding the nature of extended urbanization (see Gandy, 2014; Ranganathan and Balazs, 2015). Much of this work similarly uses the concept of metabolism in examining flows of water, energy and waste that are integral to the survival of cities, but further link them with non-urban sites, both near and far (e.g. Silver, 2015; Loftus and March, 2016; Huber et al., 2017). An important strand of research in this area is that of urban electricity networks and their dependence on hydropower generation in sites that could not be more remote from the cities that they serve. Silver (2015), for example, demonstrates how electricity interruptions in urban Africa stem from an over-reliance on hydro-power. This point supports the author's larger argument that the intensifying nature of urbanization necessitates the exploitation of more energy-intensive forms of urbanization and increased inequality both in cities and the places which bear the costs of their growth. In this way, writing on the urban political ecology of infrastructures enables a more complete understanding of the politics, ecologies and

\footnotetext{
${ }^{7}$ Water has been a primary empirical and analytical lens for urban political ecologists, particularly in order to illustrate the power relations and social injustices bound up with the urbanisation of water (see, e.g. Brechin, 2006; Loftus, 2006; Kooy and Bakker, 2008).
} 
metabolisms of urbanization, as well as demonstrating the importance of the 'site-multiple' approach for parsing the connections between cities and their hinterlands (see Huber, 2017).

The approaches outlined in this section thus seem to constitute a more productive way of renewing attention to the expansive, ecological and political nature of contemporary urbanization as process, than abandoning or even reformulating the conceptual foundations of the UPE school. Moreover, they retain and push forward the rich conceptual tools and insights of UPE, many of which originate outside of Lefebvrian approaches. Chief among these is the concept of urban-metabolism which offers a dynamic way of analysing the emerging connections; spatial transformations and (more-than-human) relationships that are associated with urban expansion. Together with a methodological focus on everyday practice and lived experience, they are better able to pinpoint the various sites that are bound up with the process of urbanization. Finally, as noted above, these bodies of work are not the only examples of work in UPE which can add productively to the insights of planetary urbanization. Rather, they are meant to be indicative of emergent forms of analysis that can chart the new phenomena that are (re)shaping the urban, both as site and process.

\section{Conclusion}

This paper has sought to show how, contrary to the critiques of 'methodological cityism', the urban political ecology literature is particularly well-suited to 'work across traditional disciplinary divisions and provide insights into a new era of planetary urbanization' (Angelo and Wachsmuth, 2015: 1). In evaluating the critiques of planetary urbanization scholars, I have argued that to claim the majority of research on UPE to be guilty of methodological cityism is to overlook many of the sub-field's important contributions, the vibrancy of which account for the strength and vitality of the body of literature. As Latour (2010) has argued, this is a fundamental problem with the analytical method of critique, in that it can only debunk, dismantle, and demolish. As such, I have responded by way of composition, which has attempted to stitch together existing work within urban political ecology with the insights of the planetary urbanization literature, rather than foreclosing one form of analysis in favour of another, more 'realistic' concept or theory. This includes traditional writing in UPE on socio-natural and urban-rural metabolisms; the production and urbanisation of nature; as well as more recent engagements with poststructural and post-humanist theory. 
The various strands of UPE research reviewed here important for highlighting the significant socio-ecological effects of extended urbanization. The cases show how concepts such as urban metabolism can aid in understanding the multi-scalar and transnational connections that link contemporary cities with places elsewhere. The review of this work has reinforced the point that UPE does actually examine the urbanization of nature, rather than simply the occurrence of nature in the city (see Kaika and Swyngedouw, 2011). This is premised on the view of the urbanization of nature as a dialectic process - which necessitates engaged urban research - while also being sensitive to relations with sites elsewhere. As such, the paper has argued that these insights can be further developed through a focus on the everyday practices and experiences of actors that constitute cities and their more-than-urban geographies.

In particular, the methodological insights of the site multiple and boundaries and edges encourage us as researchers to follow actions, and in doing so, explicate the relevance of our findings to different, though related, sites. If we as scholars were to arbitrarily determine that the urban is everywhere, then the empirical phenomenon that we study and the practices through which they are enacted would count for nothing, 'since we would be presuming to know in advance who and what was relevant and how they are arranged' (Lepawsky and Mather, 2011: 247; see also Latour, 1987). This speaks to the import of approaches such as situated urban political ecologies and everyday urbanisms in understanding the ways in which landscape transformation is experienced and contested on an everyday basis by urban residents, and the complex factors involved in managing contemporary urban landscapes.

\section{References}

Angelo, H. (2016) From the city lens toward urbanisation as a way of seeing: Country/city binaries on an urbanising planet, Urban Studies 54.1, 158-178.

Angelo, H. and D. Wachsmuth (2015) Urbanizing urban political ecology: a critique of methodological Cityism. International Journal of Urban and Regional Research 39.1, 16-27.

Arboleda, M. (2016a) Spaces of extraction, metropolitan explosions: planetary urbanization and the commodity boom in Latin America. International Journal of Urban and Regional Research 40.1, 96-112.

Arboleda, M. (2016b) In the nature of the non-city: expanded infrastructural networks and the political ecology of planetary urbanisation. Antipode 48.2, 233-251.

Braun, B. (2005) Environmental Issues: writing a 'more than human' urban geography. Progress in Human Geography 29.5, 635-650.

Brechin, G. (2007) Imperial San Francisco: urban power, earthly ruin, California studies in critical human geography, Univ. of California Press, Berkeley. 
Brenner, Neil (ed.) (2014) Implosions - explosions: towards a study of planetary urbanization. Jovis, Berlin.

Brenner, N., D.J. Madden and D. Wachsmuth (2011) Assemblage urbanism and the challenges of critical urban theory. City 15.2, 225-240.

Brenner, N. and C. Schmid (2014), The 'Urban Age' in Question. International Journal of Urban and Regional Research 38.3, 731-755.

Bridge, G. (2000) The social regulation of resource access and environmental impact: production, nature and contradiction in the US copper industry. Geoforum 31, 237-256.

Bunnell, T. and A. Maringanti (2010) Practising urban and regional research beyond metrocentricity. International Journal of Urban and Regional Research 34.2, 415-420.

Cadieux, K.V. (2008) Political ecology of exurban 'lifestyle' landscapes at Christchurch's contested urban fence. Urban Forestry \& Urban Greening 7, 183-194.

Connolly, C. (2016) 'A place for everything': moral landscapes of 'swiftlet farming' in George Town, Malaysia. Geoforum 77, 182-191.

Connolly, C. (2017) Landscape political ecologies of urban 'swiftlet farming' in George Town, Malaysia. Cultural Geographies 24.3, 421-439.

Cook, I. (2006) Geographies of food: following, Progress in Human Geography 30.5, 655-666.

Cornea, N.L., R. Véron and A. Zimmer (2017). Everyday governance and urban environments: Towards a more interdisciplinary urban political ecology. Geography Compass 11. DOI: e12310.

Crang, M. and I. Cook (2007) Doing ethnographies. Sage, Los Angeles.

Cronon, W. (1991) Nature's metropolis : Chicago and the Great West. W.W. Norton, New York.

Darling, E. (2005), The city in the country: wilderness gentrification and the rent gap. Environment and Planning A 37, 1015-1032.

Davis, M. (1998) Ecology of fear: Los Angeles and the imagination of disaster. Metropolitan Books, New York.

Davis, M. (2002) Dead cities, and other tales. The New Press, New York.

Derickson, K.D. (2015) Urban geography I: locating urban theory in the "urban age". Progress in Human Geography 39.5, 647-657.

Farías, I. and T. Bender (eds.) (2011) Urban assemblages: how actor-network theory changes urban studies, Questioning Cities Series, Routledge, London.

Freidberg, S. (2001) Gardening on the edge: the social conditions of unsustainability on an African urban periphery. Annals of the Association of American Geographers 91.2, 349-369.

Freidberg, S. (2004) French beans and food scares culture and commerce in an anxious age. Oxford University Press, New York.

Gandy, M. (2004) Rethinking urban metabolism: Water, space and the modern city. City 8:3, 363-380.

Gandy, M. (2014) The fabric of space: water, modernity, and the urban imagination, The MIT Press, Cambridge, Massachusetts.

Graham, S. and S. Marvin (2002) Splintering urbanism networked infrastructures, technological mobilities and the urban condition. Routledge, London.

Gustafson, S., N. Heynen, J.L. Rice, T. Gragson, J.M. Shepherd and C. Strother (2014) Megapolitan political ecology and urban metabolism in southern Appalachia. The Professional Geographer 66.4, 664-675.

Haraway, D.J. (1991). Simians, cyborgs, and women : the reinvention of nature. Routledge, New York. Harvey, D. (2008) The Right to the City. New Left Review 53, 1-10.

Heynen, N. (2014) Urban political ecology I: the urban century. Progress in Human Geography 38.4, 598-604.

Heynen, N., M. Kaika and E. Swyngedouw (2006) Urban political ecology: politicizing the production of urban natures. In N. Heynen, M. Kaika and E. Swyngedouw (eds.), In the nature of cities: urban political ecology and the politics of urban metabolism, Questioning Cities Series, Routledge, London. 
Keil, R. and J.-A. Boudreau (2006), Metropolitics and metabolics: Rolling out environmentalism in Toronto. In N. Heynen, M. Kaika and E. Swyngedouw (eds.), In the nature of cities: urban political ecology and the politics of urban metabolism, Questioning cities series, Routledge, London.

Keil, R. and J. Graham (1998) Reasserting nature: constructing urban environments after Fordism. In N. Castree and B. Braun (eds.), Remaking reality: nature at the millenium, Routledge, London.

Keil, R. and S. Macdonald (2016) Rethinking urban political ecology from the outside in: greenbelts and boundaries in the post-suburban city. Local Environment 21.12, 1516-1533.

Kooy, M. and K. Bakker (2008) Splintered networks: The colonial and contemporary waters of Jakarta, Geoforum 39(6), 1843-1858.

Latour, B. (1987) Science in action : how to follow scientists and engineers through society. Harvard University Press, Cambridge, Mass.

Latour, B. (1993) We have never been modern, Harvard University Press, Cambridge.

Latour, B. (2004) Why has Critique Run out of Steam? From Matters of Fact to Matters of concern. Critical Inquiry 30.2, 225-48.

Latour, B. (2005) Reassembling the social: an introduction to actor-network-theory. Oxford University Press, Oxford.

Latour, B. (2010) An attempt at a 'compositionist manifesto'. New Literary History 41.3, 471-490.

Lawhon, M., H. Ernstson and J. Silver (2014) Provincializing urban political ecology: towards a situated UPE through African urbanism. Antipode 46.2, 497-516.

Lefebvre, H. (2003 [1974]) The urban revolution, University of Minnesota Press, Minneapolis.

Lepawsky, J., G. Akese, M. Billah, C. Conolly and C. McNabb (2015) Composing urban orders from rubbish electronics: cityness and the site multiple. International Journal of Urban and Regional Research 39.2, 185-199.

Lepawsky, J. and C. Mather (2011) From beginnings and endings to boundaries and edges: rethinking circulation and exchange through electronic waste, Area 43.3, 242-249.

Lockhart, A. (2015) Developing an offsetting programme: tensions, dilemmas and difficulties in biodiversity market-making in England. Environmental Conservation 42.5, 335-344. 
Loftus, A. (2006) The metabolic processes of capital accumulation in Durban's waterscape. In N. Heynen, M. Kaika and E. Swyngedouw (eds.), In the nature of cities: urban political ecology and the politics of urban metabolism, Questioning Cities Series, Routledge, London.

Loftus, A. (2012) Everyday environmentalism: creating an urban political ecology. University of Minnesota Press, Minneapolis.

Loftus, A. and H. March (2016) Financializing desalination: rethinking the returns of big infrastructure. International Journal of Urban and Regional Research 40.1, 46-61.

McFarlane, C. (2011) Assemblage and critical urbanism. City 15.2, 204-224.

McFarlane, C. and J. Silver (2017) Navigating the city: dialectics of everyday urbanism. Transactions of the Institute of British Geographers 42.3, 458-471.

McFarlane, C., J. Silver and Y. Truelove (2016), Cities within cities: intra-urban comparison of infrastructure in Mumbai, Delhi and Cape Town, Urban Geography, 1-25.

McLean, H. (2017) In praise of chaotic research pathways: A feminist response to planetary urbanization. Environment and Planning D: Society and Space.

Marx, K. (1976) Capital. Vol. 1. Penguin, Harmondsworth.

Meijers, E., M. Hoogerbrugge and K. Hollander (2014) Twin cities in the process of metropolisation. Urban Research \& Practice 7.1, 35-55.

Mitchell, C.L. (2008) Altered landscapes, altered livelihoods: the shifting experience of informal waste collecting during Hanoi's urban transition, Geoforum 39.6, 2019-2029.

Mol, A. (2002) The body multiple: ontology in medical practice, Science and Cultural Theory series, Duke University Press, Durham.

Neo, H. and C.P. Pow (2015) Eco-cities and the promise of socio-environmental justice. In R.L. Bryant (ed.), International Handbook of Political Ecology. Edward Elgar.

Neumann, R.P. (2011), Political ecology III: Theorizing landscape, Progress in Human Geography 35.6, $843-850$.

Newman, A. (2015) Landscape of discontent: urban sustainability in immigrant Paris, A quadrant book, University of Minnesota Press, Minneapolis.

Parés, M., M., H. March and D. Saurí (2013) Atlantic Gardens in Mediterranean Climates: Understanding the Production of Suburban Natures in Barcelona. International Journal of Urban and Regional Research 37.1, 328-347.

Pow, C.P. and H. Neo (2013) Seeing Red Over Green: Contesting Urban Sustainabilities in China, Urban Studies 50, 2256-2274.

Ranganathan, M. and C. Balazs (2015) Water marginalization at the urban fringe: environmental justice and urban political ecology across the North-South divide. Urban Geography 36.3, 403-423.

Rice, S. and J. Tyner (2017) The rice cities of the Khmer Rouge: an urban political ecology of rural mass violence. Transactions of the Institute of British Geographers 42.4, 559-571.

Robbins, P. (2007) Lawn people: how grasses, weeds, and chemicals make us who we are. Temple University Press, Philadelphia.

Robbins, P. and J. Sharp (2006) Turfgrass subjects: the political economy of urban monoculture. In The nature of cities: urban political ecology and the politics of urban metabolism, Questioning Cities Series, Routledge, Abington and New York.

Robinson, J. (2002) Global and world cities: a view from off the map. International Journal of Urban and Regional Research 26.3, 531-554.

Ross, A. (2011) Bird on fire: lessons from the world's least sustainable city. Oxford University Press, Oxford.

Roy, A. and A. Ong (eds.) (2011) Worlding cities: Asian experiments and the art of being global. Studies in Urban and Social Change series, Wiley-Blackwell, Chichester.

Saguin, K. (2017) Producing an urban hazards cape beyond the city. Environment and Planning A 49.9: 1968-1985.

Silver, J. (2015) Disrupted Infrastructures: An Urban Political Ecology of Interrupted Electricity in Accra. International Journal of Urban and Regional Research 39.5, 984-1003. 
Scott, A.J. and M. Storper (2015) The Nature of Cities: The Scope and Limits of Urban Theory. International Journal of Urban and Regional Research 39.1, 1-15.

Simone, A.M. (2010) City life from Jakarta to Dakar: movements at the crossroads. Global Realities series, Routledge, New York.

Smith, N. (1984) Uneven development : nature, capital, and the production of space. Blackwell, New York.

Swyngedouw, E. (1996) The City as a Hybrid -- On Nature, Society and Cyborg Urbanization, Capitalism Nature Socialism 7.2, 65-80.

Swyngedouw, E. (1997) Power, nature, and the city. The conquest of water and the political ecology of urbanization in Guayaquil, Ecuador: 1880-1990. Environment and Planning A 29, 311-22.

Swyngedouw, E. (2004) Social power and the urbanization of water: flows of power. Oxford University Press, Oxford.

Swyngedouw, E. (2006) Circulations and metabolisms: (Hybrid) Natures and (Cyborg) Cities. Science as Culture 15.2, 105-121.

Swyngedouw, E. (2015) Liquid power: water and contested modernities in Spain, 1898-2010. Urban and industrial environments. The MIT Press, Cambridge.

Swyngedouw, E. and N. Heynen (2003) Urban Political Ecology, Justice and the Politics of Scale. Antipode 35.5, 898-918.

Taylor, L.E. and P.T. Hurley (2016) A Comparative Political Ecology of Exurbia: Planning, Environmental Management, and Landscape Change. Springer, Switzerland.

Tsing, A.L. (2005) Friction: an ethnography of global connection, Princeton University Press, Princeton. Wachsmuth, D. (2014) City as ideology: reconciling the explosion of the city form with the tenacity of the city concept. Environment and Planning D: Society and Space 32.1, 75-90.

Walker, P. and L. Fortmann (2003) Whose Landscape? A political ecology of the "exurban" Sierra. Cultural Geographies 10, 469-491.

Walker, R. (2015) Building a better theory of the urban: A response to "Towards a new epistemology of the urban?". City 19.2-3, 183-191.

Whatmore, S. (1999) Hybrid Geographies: Rethinking the "Human" in Human Geography. In D. Massey (ed.), Human geography today. Polity Press, Cambridge.

Yeo, J.-H. and H. Neo (2010) Monkey business: human-animal conflicts in urban Singapore. Social \& Cultural Geography 11.7, 681-699. 